\title{
Calling for Harmony
}

\author{
Dingming Wang \\ Department of English Sichuan Agricultural University, Ya’an, Sichuan, 625014, China \\ wangdingming@163.com
}

\begin{abstract}
Though Nutting is read as a process of natural ravishment, but as an allegory, it is Wordsworth's contemplation of nature and human society. With vivid description of the narrator's feeling through whole process of nutting, Wordsworth reveals the relationship between Nature and human society. With the mutilated scene at end, he suggests it should develop a new harmonious relationship between Nature and human society.
\end{abstract}

Key word: Wordsworth harmony Nutting nature

"Nutting" is one of these poems that Wordsworth wrote during his hard times in Germany in 1798. It is a narrative description of Wordsworth's boyhood experience. The poem itself is "a process of natural ravishment" (Curran 233), telling the story how a boy broke the beautiful scene of nature in order to get nuts. While Austin suggests that "Nutting" reflects "the destructive side of man" which is "part of man's learning process" (173), Jacobus holds that it is "a poem of instruction and Wordsworth's most obviously sexual and sexualizing approach to the question of nature's gender" (254). From different points of view, scholars reveal many potential intentions of Wordsworth, even far beyond the discussion on the gender of nature. Though with many explanations, there is one thing in common. Wordsworth is a worshiper of Nature. It is acceptable to take a look how Wordsworth describes Nature in his work in order to find out what he thinks about it. Wordsworth has seen the destruction that human society has brought to nature in his time. He might seek out a better relationship between human society and nature. From this point of view, "Nutting" can be read as an allegory. Wordsworth tries to suggest a new harmonious relationship between human society and nature by revealing the true relation between them.

In "Nutting", the narrator marches into the nook to collect nuts. As the only person in this poem, the narrator represents the human society, and the nook where he collects nuts represents Nature. The relationship between the nook and the narrator symbolizes the relationship between Nature and the human society.

In the beginning, the narrator tells the time of the event. It happens in an ordinary day, "One of those heavenly days that cannot die". It suggests that such kind of action could happen on any day of life. And the action is one part of life. It should not be surprised to see it. The purpose of nutting is not for food, but in "the eagerness of boyish hope". The boyish hope is understood as a desire to show one's abilities instead of making a living. In his pleasure principles, Epicurus distinguishes different kinds of desires: natural and necessary, such as food; natural and unnecessary, such as sexual pleasure; neither natural nor necessary, such as luxury or popularity (qtd. in Stumpf 112). As Ross discusses that "Nutting" better displays the "struggle" to claim man's self-determination (393), the desire of the narrator is neither natural nor necessary. He probably wants to justify his ability, or get some knowledge. Having fed himself already, the narrator needs to do something more. The narrator shares some common ground with human society towards Nature. Man gets supply from Nature. But not all he wants are basic. Food is the natural and necessary desire, but gold is not. Many things like gold are neither natural nor necessary ones. From things Man gets from Nature, human society asks far more than it needs from Nature. The narrator's action is beyond his necessary desire.

When the narrator starts out, he has some knowledge of how to get nut from the hazel trees. He is well equipped, "a huge wallet", "a nutting-crook", and ragged clothing. The huge wallet stores his gains, the nutting-crook helps him to low the bough and branch to collect the nuts, and the ragged clothing protects him from thorns. All those are the advices from his "frugal Dame". With all the knowledge and equipments, he is ready to get things nature. In this case, he is in process of becoming a ravisher of Nature. The narrator is innocent at first and does not know the result his future action will give to Nature and he will become a ravisher. Not until he sees what he has done that he knows the negative effect of his action. As Austin's point of view, the way man does with nature is part of man's learning process. Before action, Man doesn't know what will happen next. Later, Man learns the result of his action. But for this learning process, both man and Nature pay a price, especially Nature. During Wordsworth's time, the industry has greatly developed and the society steps into a high speed of development. In order to meet the fast increasing needs of the society, human society exploits whatever it can get from Nature. Just like the innocent boy, at that time, the society has had some knowledge about Nature and knows how to get materials from it in some fields. Then, no one knows the result of exploration of Nature. There is little to be done in protecting Nature. From today's points of view, man who lived a hundred years before did not know how to utilize materials efficiently. It is more likely to happen that man lives one hundred years later will think the present man that way. Man meets his desires and gains knowledge by sacrifice Nature.

With the desire and knowledge, the narrator goes on his journey. He goes over "pathless rocks" and passes through "beds of matted fern, and tangled thickets", and comes to an unvisited nook. With his knowledge, he knows that he will probably have a good harvest in some places that no one goes. With this idea, he comes to this virgin place. There is no "sign of devastation", the "broken bough | Drooped with its withered 
leaves". It seems that for many years that no one comes here to collect nuts. It is a good place for exploitation. Since Christopher Columbus first discovered America in 1492, Nature was believed to have inexhaustible resources and the unvisited land represents fortune and wealth. Immigrants rushed to new continents and hoped to become rich in the new land. When the narrator sees this unvisited place and the hanging nuts, he is filled with joy in his heart. This is "A temper known to those, who after long | And weary expectation, have been blest | With sudden happiness beyond all hope". The reality meets the expectation of the narrator. He could make his dream into fact. This kind of happiness resembles the happiness that might appear in Columbus' mind when he discovered America. Man believes that Nature has all things he needs and can meet all his desires.

Later, as the narration goes on, this enjoyment gets some changes. At first, the narrator enjoys the beautiful scene. He plays with flowers, listens to the murmuring of water among the sheep-like rocks. Then, he is conscious of the purpose of his journey-nutting. He finds his heart is luxuriating "with indifferent things". When the idea that it is wasteful to enjoy such beautiful things without fulfillment of his mission comes into his mind, the narrator recalls his purpose of mission. Nature turns into things without life. At that time, Nature is not the nature of the old time. After the age of Enlightenment, with great development of science, the mysterious veil of Nature is removed. Under microscope, Nature is examined into details. The thorough inspection deprives the spirit from Nature. In ancient Greece, the Greeks believe that Nature has spirits. There are many nymphs of wood in Greek mythology. Pan is called "the Lord of the Wood" (Frazer 610). But now those gods disappears and Nature becomes "indifferent things" to human being. In the eyes of human, Nature is only the provider of man's materials and the object of man. It is something without vitality.

Having recalled his mission, the narrator begins to collect nuts. He uses his nutting-crook to drag branch and bough to earth so that it is easy for him to collect nuts. After some hard work, he probably fills his "huge wallet", and is "rich beyond the wealth of kings". The narrator harvests from Nature and also fulfils his mission. On the one hand, he fulfills his mission; on the other hand, he proves that he has power to conquer Nature. Curran looks at this action as a "natural ravishment" (233). It is Nature as the object that offers the narrator place to justify his identity. The deformed and sullied nook represents the state of Nature then. Nature is not only the sources of man's life, but also the object of conquers. The relationship between Nature and man is the relationship between conquest and conqueror. The narrator's action is destructive. The price of nuts is the broken of branch and bough. He does not know how to protect them when he collects nuts. He is unconscious that if he protects these bough and branch, he may come here next year and will have another good harvest. When man exploits natural resources, he does the same thing. He never considers making good use of natural resources, and does not know the negative effect of his action to the environment and Nature. It still happens today.

Experienced the change of Nature in his mind, the narrator still bears the thought there is something special in Nature. At the end of poem, he says: "there is a spirit in the woods". Wordsworth claims he is a worshiper of Nature, but his religion is still in debate. Gaskell thinks that Wordsworth keeps the same distance from pantheism and deism (18). He may not be a complete pantheist, but he probably looks at Nature as a living thing, and does not like his contemporaries to treat it as an indifferent thing. Some evidence shows that Wordsworth really believes that the woods have a spirit. In the draft of "Nutting", Wordsworth uses two more times the word "spirit" in the poem than the present one:

They led me far,

Those guardian spirits, into some dear nook

Unvisited

After the ravishment,

the shady nook

Of hazels, and the green and mossy bower,

Deformed and sullied, patiently gave up

Their quiet spirit. (qtd. in Gaskell 14)

The words "those guardian spirits" and "quiet spirit" disappeared in the second edition of Lyrical Ballads (1800), but they show Wordsworth's intention. He believes there is a spirit in Nature.

And also, with some distinct characters, Nature is more like a human being in the eyes of the narrator.

First, it has fertility and can cure the wound itself. When the narrator comes to the unvisited nook, he sees "A virgin scene". But it does not mean this is a place that no one has ever come. Though this nook is behind the "pathless rocks", "matted fern, and tangled thickets", one may come here like the narrator. For the narrator, it is the first time he comes here, but for other people, they may come here long before. The narrator sees no "broken bough | Drooped with its withered leaves, ungracious sign | Of devastation" because since the last one comes here, "the violets of five seasons re-appear | And fade". Five years have past, and the bough and branch dragged to earth has perished and disappeared. The hazel trees grow new bough and branch. Five years are enough for the woods to recover from the wound. So in the eyes of the narrator, it is a "virgin scene" and gives him great joy. The passage of time shows the great fertility of Nature.

Second, Nature is humble and tolerant. It never intends to show its treasure in conspicuous place. The hazel trees are behind "pathless rock", "beds of matted fern". When the narrator forces his way and arrives at the nook, they show the rich fruits they have without concealment. Maybe for many times, those trees have been ravished. But they still keep showing its treasure to the visitor. These are all the things the visitor wants. When the narrator takes his action, the trees patiently give up. It is unnecessary to resist. Such action may happen again and again in the past, and Nature bears the rudeness of man without complains. Such humility and 
tolerance probably give deep impression to the narrator. Man should learn these two characters from Nature.

With the idea of spirit in Nature, the narrator develops new feelings. When the narrator saw "the silent tree" and "the intruding sky", he "felt a sense of pain". Nature has a spirit, and some characters like man. It should not treat it in such rude way. It is no fault that he collects nuts from the trees. If he does not come to collect the nuts, the nuts will also fell to the ground and decay. It is the natural law. What is wrong is the way he collects them. There is no gentle touch, but "the savage rape" of nature (Curran 232). Now, in the eyes of the narrator, Nature is the "dearest Maiden". It has a spirit and is not the indifferent things. It provides all things he wants. He should treat it more gently. After the harvest, the former nutcollector has abandoned it and forgot it. It may also happen to the narrator. So the narrator has the sense of pain. With "gentle hand touch", the narrator supposes a better way of collecting nuts. If he does not use the present way of nutting, but improves it without injury to the trees, he may come here next year for a good harvest. It means he needs not to drag bough and branch to earth. In this way, he will not feel pain. Human society is also rude to Nature. Man has exploited Nature and abandoned it when he finds nothing valuable left. A nook may recover in five years, but Nature is not so. For many natural resources, they are irrecoverable. If they are used up, they cannot recover again. So human society should know more about Nature, and make best use of all natural resources. The changing feelings of the narrator suggest a harmonious relationship should be built between human society and Nature.

In "Nutting", the narrator experiences the change of feelings towards Nature. With the mission to collect nuts, he starts out with desire, equips with knowledge, find the nook with joy, treats the hazel trees without vitality, collects nuts without protecting bough and branch, and has sympathy with Nature. The description of feelings of the narrator stands out instead of commentary. But what Wordsworth describes gives much sense. It proves what he says in Preface to Lyrical Ballads (1800): "the feeling therein developed gives importance to the action and situation" (Wordsworth 73). What he describes is the real emotion in the mind of the narrator. There is no moral commentary. He just let the readers to think about it. But when he later talks about industrial revolution, he says in a letter to a friend: "I see clearly that the principal ties which kept the different classes of society in a vital and harmonious dependence upon each other have, within these thirty years, either been greatly impaired or wholly dissolved" (qtd. in Ford 15). In the past, man has developed some good relationships with Nature. But with the rapid development of human society, these relationships have been broken. Wordsworth does not give apparent answer to the issue. But what he suggests is a harmonious relationship with Nature. In ancient, our forefathers have successfully turned from the hunting society into agriculture society. Now it is possible to build up a new harmonious relationship with Nature if the human society can treat Nature as a divine being like our forefathers.

\section{References}

[1] Austin, Frances, The Language of Wordsworth and Coleridge, Houndmills: Macmillan, 1989.

[2] Curran, Stuart, ed., The Cambridge Companion to British Romanticism, Cambridge: Cambridge University Press, 1993.

[3] Ford, Boris, ed., From Blake to Byron: The Pelican Guide to English Literature 5. Middlesex, England: Penguin Books, 1957.

[4] Frazer, James George, The Golden Bough: A Study in Magic and Religion, abridged ed., London: MacMilan and Co. Ltd., 1963.

[5] Gaskell, Ronald, Wordsworth's Poem of the Mind: An Essay on The Prelude, Edinburgh University Press, 1991.

[6] Jacobus, Mary. Romanticism, Writing, and Sexual Difference: Essays on The Prelude, Oxford: Clarendo Press, 1989.

[7] Ross, Marlon, "Naturalizing Gender: Woman's Place in Wordsworth's Ideological Landscape," ELH, vol. 53, no. 2, pp. 391-410, Summer 1986.

[8] Stumpf, Samuel Enoch, Socrates to Sartre: A History of Philosophy, $5^{\text {th }}$ ed., New York: McGraw-Hill, 1993.

[9] Wordsworth, William, "Preface to Lyrical Ballads" (1800) in Wordsworth's Literary Criticism, W. J. B. Owen Eds., London and Boston: Routledge \& Kegan Paul, 1974.

[10] Wordsworth, William, Selected Poems, New York: Penguin Books Ltd., 1996. 